\title{
NEW ORIENTAL ANTHRIBIDAE (COLEOPTERA).
}

BY DR. KARL JORDAN, F.R.S.

\section{Mecotropis arduus sp. nov.}

o. Close to $M$. annulipes Jord. 1911, from Borneo; dark dots at suture more sharply defined, otherwise the colouring of the body the same. Proboscis longer. Segment II of antenna more gradually conical, being less strongly narrowed in basal two-thirds than is the case in $M$. annulipes. Groove in front of forecoxae not continued as in $M$. annulipes across middle by a shallow curved depression. A long subapical spot on tibiae, this spot on mid- and hindtibiae about as long as the black apex, on foretibia shorter, tarsi black, a subapical spot on segment I of all tarsi, occupying on foretarsus about one-fourth of the length of the segment, on mid- and hindtarsi two-fifths, colour, of spot yellowish, segment IV the same colour except its apex and the elaw.

Length : $18 \mathrm{~mm}$.

Malay Peninsula: Selangor, Bukit Kutu, 3,500 ft., 14.ix.1929 (H. M. Pendlebury), 1 ô.

\section{Mecotropis ordinatus sp. nov.}

․ Like M. marmoreus Jord. 1895, from Borneo and the Malay Peninsula, but with definite white spots. Antennal segments IX to XI a little broader. Pubescence buffish grey, rather sparse, not concealing the black colour of the derm. A broad median stripe on head and rostrum more densely pubescent, an elliptical or ovate darker median spot posteriorly between the eyes, in one specimen continued backwards. On pronotum at each side close to middle line two white spots, one before middle, the other at carina, sidewards from them and a little more forward a dot, the second spot barely traceable in two of the three specimens. Scutellum white. Adjoining it a small white sutural spot; each elytrum with the following white spots: a dorsal row of 5 , at nearly equal distances from one another, the first on basal incrassate margin, the last two on apical declivous area smaller than the second and third, a sixth spot above shoulder, at margin 5 or 6 , the first below shoulder long, the second small, the fifth and sixth submarginal, small.

Underside spotted with white. Tarsal segment I with a minute white spot, II with basal third or two-fifths white.

Length : 11 to $12 \mathrm{~mm}$.

Malay Peninsula: Selangor, Bukit Kutu, 3,500 ft., 14.ix.1929 (H. M. Pendlebury), 3 ㅇ․

\section{Physopterus pulcher sp. nov.}

o. In colouring recalling $P h$. opulentus Jord. 1913, but elytra not humped in front of apical declivity. Black-brown, with tawny markings, the tawny pubescence interspersed with white grass-blade hairs, which are especially conspicuous on the black-brown interspaces.

Proboscis tawny above, as long as subapically wide, a median sulcus extend- 
ing on to frons, but separated from apical margin by a median carina; from upper margin of antennal groove backwards two diverging swellings ; ill-defined, not reaching eye; below eye an oblique groove; underside rugate-punctate. Antennal groove sulciform, ending with a rounded hole. Frons and occiput tawny, the latter with a black dorsal elongate spot each side of middle, the spots parallel. Antenna reaching to end of elytra, black, with white pubescence, which is concentrated at apices of segments, VIII entirely and IX at base white, X and XI without white pubescence.

On pronotum, from carina to apex, five pairs of tawny spots, second pair partly confluent with anterior spot of middle pair, the spots occupying about as much room as the black-brown interspaces; behind carina a spot near lateral angle and three spots in middle area, tawny. Scutellum white.

Elytra somewhat flattened dorsally to behind middle, evenly convex in posterior half, suture and alternate interspaces spotted with tawny, most of the spots longer than broad, about six or seven in an interspace. Pygidium evenly rounded, one-sixth broader than long, with brown basal median spot, and another each side halfway to apex.

Underside with tawny, confluent, somewhat diffuse spots at side, middle sparsely pubescent grey; metasternum with a minute tuft each side of middle line near apex ; abdominal segment I with a round median tubercle some distance from apex. Pubescence on femora, except apices, and on tarsi grey-white, on apices of femora and on tibiae tawny.

Length : $9 \mathrm{~mm}$.

Malay Peninsula: Larut Hills, Perak, 3,700 to 4,000 ft., 11.xi.1932 (H. M. Pendlebury), 1 ô.

\section{Physopterus biplagiatus ovatus subsp. nov.}

․ Black patch of elytrum reaching from lateral margin to line III of punctures, transversely longer than longitudinally (ratio $4: 3$ ), its longitudinal diameter shorter than in Ph. bipl. biplagiatus Jord. 1897.

Java, 1 ․

Atoporhis gen. nov.

$\hat{o}+$. Near Altipectus Jord. 1894, but rostrum with several carinae and segment VIII of antenna little longer than broad.

Rostrum spathulate, porrect, with large apical triangular median flattened area reaching halfway to base, a high median earina from this triangle to base and on to frons, but not extending to occiput, this carina convex in lateral aspect, it is flanked by a deep sulcus, upon which follows a heavy carina running from eye straight to depressed triangle and then turning obliquely to apical lateral angle, the carina flanking the triangle and becoming flat at apex ; at the side of it from eye to above antennal groove a broad sulcus bounded laterally by a subcariform swelling; below this a narrow curved groove; on underside, buccal sinus long and narrow, continued by a short shallow sulcus which ends with a rounded groove situated below the inner end of the antennal groove, but a little nearer to head. Antennal groove larger than in Altipectus. Antenna similar, but VIII quite short.—Genotype: A. plastus sp. nov. 


\section{Atoporhis plastus sp. nov.}

o. Brown-black, the derm of upperside and flanks of underside for the greater part rufous; pubescence dense, greyish cinnamomeous on head, pronotum, elytra, and sides of pygidium, whitish grey on proboscis, underside, and legs. Rostrum one-twelfth longer than broad. Eye elliptical. Frons as broad as segment I of antenna $(\hat{\sigma})$. Antenna brownish black, reaching a little beyond base of pronotum, flattened (in $\hat{\sigma}$ ) from segment III, III as long as I + II, length of III 29 , IV $20, \mathrm{~V} 18$, VI 15, VII 16, VIII 8, IX 31, X 15, XI 25 ; club linear, width 9.

Pronotum conical, less than one-third broader than long $(9: 7)$, with two straight brown-black stripes (extending to eyes), somewhat narrower than their interspace, and nearer to middle than to sides; carina as in Attipectus well separated from base, concave in median third, then somewhat convex, and finally flexed forward in a wide curve to middle of side, no angle being formed. Longitudinal and transverse carinulae distinct, the former directed towards the lateral carina, but not reaching it. Scutellum triangular, greyish.

Elytra widest at shoulders, broader than pronotum, gradually narrowed, dorsally flattened, punctate-striate, first two interspaces flat, the others slightly convex, a black-brown spot on subbasal swelling, elliptical, with a dot in front of it and another obliquely behind it in fifth stripe, a second spot before middle, narrower, longer than broad, occupying interspace IV and half III and V, a third, smaller, spot outside it but joined to it in interspace VI, a large spot, the largest of all, in apical third from interspace III to VII, triangular, rounded laterally (following seventh stripe of punctures), dentate anteriorly, its distance from apex of elytrum greater than from suture, at lateral margin two small spots between middle and shoulder. Pygidium flat, one-tenth broader than long, rounded at apex, almost subtruncate.

Abdominal segment I ( $\hat{\sigma})$ with a cordiform median impression covered with a short brown-black erect pile. Apex of tibiae and of tarsal segment I and segments II to IV brown-black, I of foretarsus one-ninth longer than II to IV together.

Length $10 \cdot 7 \mathrm{~mm}$., width $5 \mathrm{~mm}$.

North Borneo: Kudat, 14.ix.1927 (C. Boden Kloss \& H. M. Pendlebury), 1 ô.

\section{Atoporhis asemus sp. nov.}

․ Like the preceding, but pronotum and elytra with a pale drab pubescence which does not conceal the rufescent brown colour of the derm, and forms three stripes on the pronotum and a number of spots on the elytra; proboscis, frons and underside whitish grey, this colour extending on to the sides of the pronotum to the lateral stripe. Shaft of antenna not compressed (\&), segment III shorter than in the preceding species and IX longer (proportions 25:35). The two brown vittae of pronotum broader than the pale drab vittae, the middle vitta broader than the lateral ones. Elytra a little more deeply striate than in A. plastus, the interstices slightly more convex; the pale drab spots diffuse and irregular (probably variable); a large spot in depression behind subbasal swelling, a narrow transverse postmedian band composed of dots, a similar band on apical declivity, two limbal dots between middle and shoulder, and some small spots from scutellum to near shoulder. Pygidium rufescent brown, flat, some- 
what concave, nearly as long as basally broad, truncate, with the angles strongly rounded, apex about half as broad as base, sides almost straight, except at base. Foretarsal segment I nearly one-fifth longer than II to IV together, i.e. longer than in the previous species.

Borneo : Kuching, Sarawak, ix.1903, 1 \& (from the Sarawak Museum).

\section{Acorynus alboguttatus nigrans subsp. nov.}

๙. The three stripes of pronotum pale cinnamon from carina forward, much broader than the black interspaces, behind carina they are whitish grey and narrower than the interspaces. Elytra pale cinnamon, black spots smaller than in the other known subspecies of $A$. alboguttatus, white spots absent. On underside the white spots as large and as sharply defined as in A. a. alboguttatus Jord. 1894.

North Borneo: Bettotan, near Sandakan, vii.1927 (C. B. Kloss \& H. M. Pendlebury), 1 ô.

\section{Acorynus griseoniger sp. nov.}

․ Similar to A. melampus Jord. 1903, but the median carina of the rostrum much lower and carina III much more sharply defined, the grey pubescence diffuse, the elytra much more coarsely punctate-striate, etc.

Black, upperside with sparse grey pubescence. Rostrum coarsely punctate, practically as long as broad (ratio 18:19), median carina broadest at base, here flattened, farther forward lower, but more sharply defined, continued to near apical margin by a flattened swelling which is rendered irregular by the intrusion of large punctures, carina II somewhat higher and better defined, a little shorter than I, carina III lower, but well defined and very distinctly separated from edge of antennal groove. Frons as broad as segment II of antenna is long, with thin raised median line. Segments IX to XI of antenna not quite so long as III to VI together, $\mathrm{X}$ not quite twice as long as broad $(7: 4)$.

Pronotum coarsely punctate, somewhat uneven, in front of scutellum a rather large, conspicuous, square, yellowish grey spot in front of which is a small triangle of the same colour, behind apical margin an elongate grey median spot, at sides a subdorsal grey vitta indicated by a subapical rounded spot, before carina by a diffuse spot continued laterad along carina, and behind carina by another diffuse spot; lateral carina extending to meral suture.

Scutellum grey. Elytra coarsely punctate-striate, the interspaces much narrowed by the large seriate punctures, especially at side, in the stripes a grey inconspicuous pubescence ; a large median patch extending from suture obliquely backwards to outer margin, widest dorsally, and the greater portion of the declivous apical area almost devoid of grey lines and dots, therefore appearing black. Pygidium nearly one-third broader than long, rounded.

Underside grey, on sides of sterna with diffuse spaces bare of grey pubescence. Femora grey, black in middle and at apex, tibiae and tarsi brownish black, an antemedian ring on tibiae and an apical spot on tarsal segment I grey ; this segment shorter than II to IV together.

Length $5 \cdot 7 \mathrm{~mm}$., width $2 \cdot 7 \mathrm{~mm}$.

North Borneo: Bettotan, near Sandakan, viii.1927 (C. B. Kloss \& H. M. Pendlebury), 1 우. 


\section{Acorynus gracilentus sp. nov.}

§. In colouring recalling $A$. cludus Jord. 1895, but pronotum strongly punctate and transversely rugate.

Black-brown. Rostrum one-third broader than long, very coarsely punctaterugate, with a large median depression; this groove somewhat rounded on apical side ; three dorsal carinae, I broadest, flattened, widened at one-third of rostrum and here sending out a short spur each side, the carina ending in the depression at two-thirds, carina II slightly curved, shorter than I, distally broken up by large punctures, III somewhat longer, separate from edge of antennal groove. Frons as broad as antennal segment II, with a thin raised median line as continuation of carina I of rostrum. Occiput coarsely punctate. Antenna rufescent at base, segments IX to XI as long as III to VI, taken together.

Pronotum coarsely punctate, transversely rugate; a complete buff median stripe and a vestigial grey dorso-lateral one more distinct behind carina at angle ; carina flexed forward-downward at sides to meral suture.

Scutellum grey. Elytra coarsely punctate-striate; a sutural patch from base to near antemedian depression, a narrow elongate sutural spot behind it, and a short line each in stripes II and III luteous; a postmedian oblong spot from middle of interspace II to VI, a little wider than long, two small spots at beginning of apical declivity, three short lines in front of them, a sublateral spot behind shoulder, a lateral and a sublateral dot before middle, a lateral dot in posterior half, and a small diffuse patch each at the sutural and outer angles of apex, more or less buffish grey. Pygidium one-tenth broader than long, slightly convex, gradually and rather strongly rounded-narrowed, pubescence grey, thin, not concealing the derm.

Underside silky grey; apical margin of intercoxal process of mesosternite feebly rounded. Legs rufous, tarsi and apex of tibiae darker, especially in hindleg, no definite grey ring on tibiae, grey pubescence on upperside of tarsal segment I scattered; apex of fore- and midtibiae simple.

Length $5 \mathrm{~mm}$., width $2 \cdot 2 \mathrm{~mm}$.

North Borneo: Bettotan, near Sandakan, viii.1927 (C. B. Kloss \& H. M. Pendlebury), 1 ô.

\section{Acorynus trilineatus sp. nov.}

o. Near A. mundellus Jord. 1926; with three narrow, sharply defined, yellowish buff lines from apex of pronotum to base of elytra.

Black, pubescence of upperside blackish brown. Rostrum broader than long, coarsely rugate-punctate, pubescence greyish white as on frons, five carinae, which do not reach apex, I interrupted before middle, stopping before reaching apex, but continued to apical margin by a flattened swelling. Frons somewhat narrower than segment II of antenna, without median carina, but with a median stripe which runs from pronotum across occiput and is whitish in front and yellowish behind. Occiput coarsely punctate, punctures more or less confluent transversely. Segments IX to XI of antenna together longer than III to VI, IX shorter than XI, which is curved.

Pronotum one-fourth broader than long, conical from carina forward, coarsely punctate, transversely rugate; the three vittae about as broad as segment IX of antenna, lateral vitta anteriorly whitish, somewhat oblique, crossing over to shoulder of elytrum ; lateral carina reaching to meral suture. 
Scutellum yellowish buff. Elytra more than half as long again as broad $(8: 5)$, dorsally somewhat flattened, subbasal swelling moderate, interspaces of stripes but slightly convex, subbasal vitta confined to interspace I, and lateral vitta to interspace VII. Pygidium as long as broad, convex, slightly depressed medianly, gradually rounded-narrowed, middle of apical margin nearly straight.

Underside pubescent ashy grey. Anal sternite without tubercle. Legs grey like underside of body, tarsal segments II to IV black-brown, apex of foretibia somewhat incrassate and like that of midtibia without tooth.

Length $7 \mathrm{~mm}$., width $3.3 \mathrm{~mm}$.

North Borneo: Bettotan, near Sandakan, viii. 1927 (C. B. Kloss \& H. M. Pendlebury), 1 ô.

\section{Acorynus bifurcus sp. nov.}

o. Similar to A. ypsilon Jord. 1926, but the lateral stripe of the pronotum barely indicated, the spots of the elytra reduced, the club of the antenna shorter, and the pygidium longer.

Rostrum as in A. ypsilon. Eyes nearly contiguous. Occiput coarsely punctate. Antenna rufescent, segments IX to XI as long as III to V together (in A. ypsilon- $\hat{\sigma} \mathrm{IX}$ to $\mathrm{XI}$ as long as III to VI).

Pronotum coarsely punctate, transversely rugate-plicate, a grey median stripe, tapering at apex, lateral stripe represented by small remnants of grey pubescence before carina and near basal margin; lateral carina as short as in A. ypsilon and A. cylindricus Jord. 1894.

Scutellum the same colour as the median stripe of pronotum. Elytra coarsely punctate-striate; from before middle of punctate stripe $\mathrm{V}$, a creamy band runs to posterior third of suture and thence a little along suture posticad, in basal half numerous short, grey, inconspicuous lines in the stripes of punctures, an inconspicuous grey sutural patch behind scutellum, a few short spots in apical half and a rather more prominent small lateral spot before and again behind middle, the conspicuous posthumeral spot of $A$. ypsilon absent from the new species. Pygidium somewhat convex, as long as broad, gradually roundednarrowed, apical margin rather more strongly rounded at sides than in middle, a narrow lateral stripe grey.

Femora, part of underside of tibiae and a subbasal spot on tibiae grey, rest of legs blackish brown, rufescent at the joints; apex of foretibia broadened, beneath somewhat concave longitudinally, with a blunt tooth at each side of depression ; midtibia with sharp apical tooth.

Length $5.7 \mathrm{~mm}$., width $2.7 \mathrm{~mm}$.

North Borneo: Bettotan, near Sandakan, viii. 1927 (C. B. Kloss \& H. M. Pendlebury), 1 ô.

\section{Acorynus aratus sp. nov.}

9. As in A. cylindricus Jord. 1894, which we have from Perak and Borneo, the lateral carina of pronotum very short ; the new species is distinguished by segment $\mathrm{X}$ of antenna being much shorter and by the markings of the elytra being different.

Black, pubescence of underside and markings of upperside luteous. Proboscis as long as apically broad, with five carina as in the allied species mentioned, I thin and low from base, widened at apical third, but not extended to apex, 
II high, abbreviated distally, its apex connected by a slight, obliquely transverse, swelling with margin of antennal groove, III joining that margin, which is continued to apex of rostrum as a carina. Frons very little broader than antennal segment II, without indication of a median carinula except posteriorly. Eye narrowly margined with clay-colour. Shaft of antenna rufescent brown, III a little longer than IV, IX one-fourth longer than XI and nearly one-half longer than III, X twice as long as broad, longer than in A. cylindricus.

Pronotum coarsely punctate, transversely rugate; markings nearly as in A. cylindricus : median stripe consisting of three elongate spots, sublateral stripe strongly constricted at one-third from carina, the antecarinal portion forming a $\mathrm{U}$ with the short stripe ; carina as in A. cylindricus.

Scutellum brown. Elytra anteriorly broader than in A. cylindricus, strongly punctate-striate, with small separate luteous spots, namely, two transverse parallel ones in front of subbasal swelling, the anterior one at basal margin, on suture a slightly transverse dot in antemedian depression, and a slightly elongate one in middle, neither dot extending beyond stripe I, and a larger spot on apical area, posteriorly on subbasal swelling a dot in interspace I and behind the swelling a minute dot in III, another in III at beginning of apical declivity, in interspace $\mathrm{V}$ and partly in VI five dots, one of them close to base, minute, second above shoulder somewhat larger, third on a level with antemedian depression small, fourth before middle, round, nearly the same size as the median sutural spot, fifth at beginning of apical declivity, in VII a dot before this declivity, in VIII an antemedian spot similar to the submedian spot of $\mathrm{V}$, but more forward, at lateral margin a patch below shoulder, extending up to punctate stripe VII and drawn out backwards as a short marginal line which does not quite reach an antemedian limbal line, behind middle of margin a spot extending up to punctate stripe VII, and a triangular spot at lateral apical angle. Pygidium evenly rounded, broader than long, with a very distinct swelling each side of middle and a luteous lateral spot.

Basal half of tibiae except extreme base, and apical five-sixths of tarsal segment I luteous grey.

Length $7.3 \mathrm{~mm}$., width $3.5 \mathrm{~mm}$.

North Borneo: Bettotan, near Sandakan, viii.1927 (C. B. Kloss \& H. M. Pendlebury), 1 ․

\section{Acorynus saphis sp. nov.}

o. In colour and size like $A$. rusticus Pasc. 1860 , but very different in the frons, anal segment, and midtibia.

Somewhat narrower than $\widehat{\delta} \delta \hat{~ o f ~} A$. rusticus of the same length. Frons only as broad as the base of antennal segment II. Medium stripe of pronotum widely interrupted, lateral stripe and the half-stripe broader, intermediate short stripe far distant from carina. Pygidium as long as subapically broad, one-fifth broader at base than subapically; apex truncate, with the angles rounded.

Anal sternite very broad, truncate, shallowly and broadly bisinuate, the lateral angles rounded and more projecting than the median portion of the apical margin, in middle of segment a hairy elliptical swelling accentuated by a small groove each side. Intercoxal process of mesosternum narrower than in $A$. rusticus. Foretibia with a tooth each side of apical ventral sinus ; apex of midtibia with prominent tooth. 
Length $12 \mathrm{~mm}$., width $5 \cdot 2 \mathrm{~mm}$.

North Borneo: Bettotan, near Sandakan, 30 .vii.1927 (C. B. Kloss \& H. M. Pendlebury), 1 ô.

\section{Acorynus teuches sp. nov.}

o. In colour close to A. fenestratus Jord. 1897. Above drab grey, paler beneath, with the following black markings on upperside of pronotum between middle and lateral carina : an admedian stripe from apical margin to near earina, a small spot a short distance from carina, another towards lateral carina (quite small in type) and a spot between lateral carina and apical margin ; on elytra a rounded spot on subbasal swelling from interspace $I$ to $I V$, irregular spots at side behind shoulder and in middle, and dorsally behind middle and on apical declivity. Patch below eye orange-buff, continued on to prosternum.

Frons very narrow, as in A. saphis sp. nov. Segments IV to VII of antenna less broadened than in $A$. fenestratus, almost linear, VIII as long as III, nearly the same in shape and length as IX but somewhat narrower, IX to XI shorter than in A. saphis and A. rusticus. Pronotum finely and sparsely punctate, not rugate, much smoother than in the allied species. Pygidium remarkably long, one-tenth longer than basally broad, subapically only one-eighth narrower than basally, apex more strongly rounded at sides than in middle.

Intercoxal process of mesosternum as narrow as in A. saphis. Anal sternite without tubercle, medianly longer than the two preceding segments together, apical margin strongly rounded, more so at sides than in middle. Legs slenderer than in $A$. saphis and A. rusticus, the femora much less swollen beyond middle, apex of foretibia bisinuate, but without tooth ; midtibia with strong apical tooth ; segment II of foretarsus medianly longer than it is broad across base of apical sinus.

Length $9 \cdot 7 \mathrm{~mm}$., width $4 \cdot 7 \mathrm{~mm}$.

Malay Peninsula : Larut Hills, Perak, 3,700 ft., at light, 13.ii.1932 (H. M. Pendlebury), 1 ô, type ; Ulu Liang, Pahang, 22.viii.1907, 1 ô.

\section{Litocerus ampliatus sp. nov.}

7 . R Recognizable by the broad prothorax being strongly conical from the middle of the lateral carina to the apex, this portion of the side being straight, and by segment VIII of the $\delta$-antenna being much longer than III. Near $L$. laticollis Jord. 1894.

Pale testaceous, variegated with brown, rather densely pubescent buffish grey. Rostrum longer than broad, middle of apical two-fifths flattened, middle of basal three-fifths somewhat convex from side to side, median earina though thin quite distinct from base to depression, then very thin to apical margin, flattened out and evanescent before reaching the margin, carina II less prominent, running from base to middle and then continued by a swelling which extends obliquely apicad; below eye a distinct comma-groove bordered dorsally by an oblique swelling, from the lower end of which starts carina III ; this very thin and inconspicuous ; margin of antennal groove somewhat expanded and continued to apex as a thin carina. Frons in $\hat{\sigma}$ a little broader than segment II of antenna, in $q$ about as broad as that segment is long. Occiput brown in middle. Antenna rufescent-brown, pale at base, proportions : from III to XI in of 19, 17, $19,20,24,26,17,17,16$, in $+18,12,12,12,12,11,20,16,16$. 
Pronotum almost twice as broad as long (ratio 16:9), with deep transverse groove halfway between apex and carina, apical area strongly slanting upwards from sulcus ; buffish grey, with indications of a buffish median stripe, a brown stripe consisting of three portions bounds on each side an irregularly hexagonal median area, the main portion of the stripe slightly curved and extending from the end of the transverse sulcus to the carina, from its anterior end a streak runs obliquely to apical margin, which it reaches near middle, the posterior end of the brown stripe curves inward across the carina to base, the grey basal median spot being somewhat wider than the grey apical median interspace; from the inner angle of the brown basal spot another brown stripe runs straight forward alongside the grey median stripe, the apical half of it more or less obsolescent; halfway between the outer brown stripe and lateral carina a brown median spot, another spot between apex of lateral carina and apical margin, the spots connected with one another or nearly ; dorsal carina feebly convex from side to side, flexed forward to meral suture in an are which is more strongly curved at side than above.

Scutellum grey. Elytra buffish grey, one-third broader behind base than before apical declivity, rather strongly depressed at suture behind scutellum and again from antemedian depression to apex, interspace III being subcariniform ; interspaces striped with brown, an area expanding from shoulder to shoulder, gradually narrowing to interspace II and expanding again in front of apical declivity bears fewer brown stripes than the lateral area which extends from shoulder to beyond middle and upwards about to interspace II, this lateral (dark) area blackish brown at side; on apical declivous area the brown linear spots occupy about as much space as the grey pubescence, the lateral spots the darkest.

Pygidium one-tenth broader than long, in ô rounded-triangular, in $q$ subtruncate; buffish grey, brown in middle. Sterna of thorax with dark brown patches. Legs pale rufous, knees and a broad postmedian ring on tibiae brown.

Length $5 \cdot 7 \mathrm{~mm}$., width $2.8 \mathrm{~mm}$.

Java : Malang (Royer), one pair.

\section{Litocerus pollionis sp. nov.}

o. Near L. scalaris Jord. 1895, but the black-brown median area of pronotum strongly constricted, and the irregular sutural stripe of the elytra broken up into spots. Brown, markings buffish grey. Proboscis with five carinae, median one highest, more strongly elevate at base than farther down, reaching to middle, fading away in the postmedian shallow depression, carina II incurved in basal half, then somewhat directed outward, parallel with outer margin of rostrum, its apical half vestigial, carina III almost joining eariniform margin of antennal groove ; this margin continued as a carina to apical margin of rostrum. Frons narrow, only as broad as base of antennal segment III ; occiput and posterior portion of frons with large triangular brown median area. Antenna nearly reaching to apex of elytra, pale rufous at base, segment III longest, proportions : III 20, IV 16, VIII 18, IX 15, X 12, XI 17.

Middle of pronotum brown, this area deeply constricted in antemedian transverse sulcus, both portions nearly oblong, the anterior portion one-fourth narrower than the posterior one, the latter occupying four-fifths of the width of the pronotum ; a narrow buffish grey median line broken up into four spots, the 
spot behind sulcus obsolescent; lateral area densely buffish grey, with a longitudinal abbreviated brown line which is somewhat widened anteriorly ; carina incurved in middle, slightly convex each side of middle, laterally flexed forward in an even arc, the lateral carina somewhat inclining downward, nearly straight in middle, its tip slightly turned upward.

Scutellum brown. Elytra strongly punctate-striate, with the following buffish grey markings: a large patch at shoulder, within it a brown spot at shoulder angle, a minute sutural spot behind scutellum, a small oblong spot in punctate stripe I on posterior side of subbasal swelling, near it a second spot in II, in interspace I from antemedian depression to near middle a line, almost interrupted, followed by a brown elongate-elliptical sutural spot, in stripe II a line beginning a short distance behind antemedian depression and ending in middle, where it is almost continuous with a line in I ending at beginning of apical declivity, in stripe III a minute dot, in middle of III and IV a short oblong spot each, before declivity an elliptical spot occupying interspaces II, III, and part of IV, at the side of it a smaller spot in interspace V, obliquely behind this largish double spot a dot in stripe VI, at lateral margin a spot before middle with a sublateral one obliquely above-behind it, another spot behind middle of margin, apex occupied by a largish triangular spot extending from suture to outer margin, broader than long, anteriorly excurved.

Pygidium as long as basally broad, gradually narrowed, evenly rounded at apex, buffish grey at side, as is the underside of body. Legs rufous, base and underside of femora very pale, on tibiae a diffuse subbasal ring and the apex also paler than the rest of the tibiae. Grey pubescence on upperside of tarsal segment I scattered, denser on II.

Length $5 \cdot 3 \mathrm{~mm}$., width $2 \cdot 4 \mathrm{~mm}$.

Sumatra, 1 ô.

\section{Litocerus tagens sp. nov.}

ふิ․ Near L. infirmus Jord. 1928, from Borneo and the Malay Pen., but eyes almost contiguous in $\hat{\jmath}$, segments IV to VII of antenna longer, the light colour much more restricted on pronotum, and the angle of the carina less rounded.

Segment IV of $\delta$-antenna the longest, about one-fourth longer than III, twice as long as $\mathrm{X}$, proportions slightly variable, in type III 30 , IV 37 , VIII 26 , IX 25, X 18, XI 23 ; in ㅇIII 19, IV 15, VIII 15, IX 18, X 16, XI 19. Pronotum for the greater part blackish brown, a median stripe pale buff, constricted in the transverse antemedian sulcus, in front of carina more than half as wide as the brown lateral area, in this area a dorsal vitta represented by a row of spots, the last of them behind carina, the first long, above end of lateral carina and behind end of transverse sulvus a spot each. Elytra buff, a large brown-black area from shoulder to apical third of margin, extending upwards to line II of punctures (type) or to I, strongly narrowing above, its anterior margin much more slanting than the posterior, both somewhat irregular, from the anterior and posterior angles of its narrow sutural portion a curved line each projects towards or across suture; in the black area about middle two buff spots, one obliquely above the other, on apical declivous area a black patch with 5 or 6 anterior and 1 or 2 posterior projections, the one in interspace VIII reaching the large patch, and the most dorsal one being directed obliquely forward towards suture, between the two patches a brown cross, consisting of a transverse bar and a longitudinal line 
in $\mathrm{V}$, this line connected with the large patch or free. Pygidium a little longer than broad in $\hat{o}$ (in of of $L$. infirmus broader than long), as long as broad in $q$, gradually rounded-narrowed, with a brown median stripe.

Legs rufescent, basal half (or more) of femora, an antemedian ring on tibiae, and tarsal segments II to IV much paler.

Length $5 \cdot 7 \mathrm{~mm}$., width $2 \cdot 6 \mathrm{~mm}$.

Malay Peninsula: Perak (W. Doherty), 1 ô, type, in Mus. Brit. 3 oิ ô, 1 q Pahang, Fraser's Hill 4,000 ft., i.1929, and Cameron's Highlands, 4,800 ft., vi. 1923 (H. M. Pendlebury), in Mus. Kuala Lumpur.

18. Litocerus callias dividus subsp. nov.

o. Differs from L. c. callias Jord. 1911 (Malay Pen.) in the brown markings being reduced in size. On pronotum a brown stripe each side of middle, anteriorly about as wide as the interspace between the two stripes or somewhat narrower, divided at one-third into two stripes, the dorsal one short and thin, sometimes interrupted, the outer one about half as wide as the stripe is at apical margin. On elytra all the spots separate from each other or some of them connected by thin lines: three linear spots on suture, a minute dot in interspace II in antemedian depression, in III a line (sometimes interrupted) from near basal margin on to subbasal swelling, here joined by a thin line in IV; a thin line above shoulder in type (absent from the two paratypes), a spot on shoulder angle drawn out into a line which, in the paratypes, joins a median patch ; this patch extends from mid-IV to mid-VII, behind it in VIII a small spot joined to the patch in the paratypes; a larger patch on apical declivous area widened and sinuous in front, triangular apart from its irregularities; at outer margin three spots.

Borneo: Sarawak, Limbang R., iii.1910, 1 of (type) received from the Sarawak Museum, and Sarawak (Wallace), 1 in Mus. Brit. and another in the Hope Dept., Oxford.

\section{Tropideres scitus sp. nov.}

․ In size and shape similar to $T$. japonicus Roel. 1879, but elytra with welldefined black-brown transverse markings.

Rufescent-brown, pubescence luteous grey above, whitish grey on rostrum and beneath. Frons slightly wider than in T.japonicus + , posteriorly at eye with an elongate black-brown spot continuous with the brown occiput. Antenna entirely pale testaceous. Disc of pronotum dark brown, shaded with drab pubescence, sides and a broad median stripe luteous grey, the stripe expanded in antemedian depression; carina laterally more abruptly curved forward and lateral branch shorter than in T. japonicus.

Scutellum white. Elytra with the subbasal callosity distinctly higher than in $T$. japonicus, bearing a short transverse spot, shoulder angle the same colour, a short distance behind antemedian depression a transverse patch from line II of punctures to VI, broader than long, variable in size, the patch continued towards suture as well as towards outer margin by some small spots or indications of spots, which give the patch the appearance of sending out two projections sidewards and two towards the patch on the other elytrum; behind middle a transverse band from near suture obliquely backwards to outer margin; on apical declivous area a thin transverse spot and one or two minute dots representing another transverse band; all these markings black-brown : inter- 
space III somewhat convex from antemedian depression backwards, but not tuberculiform. Pygidium entirely grey. Tarsal segment II and apex of tibiae brown as in T. japonicus.

Burma: Ruby Mines (W. Doherty), 3 우 in Mus. Brit.

\section{Uncifer collaris sp. nov.}

o. Rufescent-brown, upperside of head and rostrum and the entire underside densely pubescent-grey, pronotum and elytra spotted and banded with grey, rufous-brown and blackish brown.

Rostrum nearly twice as broad as long (32:18), widest at basal third, apical margin excised in middle. Frons convex, narrower than the rostrum is long (ratio $14: 18$ ). Antenna reaching to middle of elytra, brown, base pale rufous, length of segments III 9, IV 8, V 6, VI to VII 7, IX 10, X 9, XI 11, VIII flattened like the club, but much narrower, VII also flattened, but less so than VIII, III the thinnest.

Pronotum granulose, somewhat depressed before middle and along carina, the centre therefore convex, a little less than the anterior half rufous, covered with a grey pubescence, which is densest in the depression, apical margin dark brown each side of middle, from this grey collar to base the pronotum blackish brown except a grey median stripe from scutellum across carina, tapering in front and not reaching grey apical border, and a grey basal lateral patch extending forward sublaterally, opposite this projection another, from apical border backwards, on upperside of this anterior grey projection a brown projection into the grey border; dorsal carina distant from base, shallowly concave medianly, and then more strongly convex, its hooked end almost touching outer surface of shoulder, the angle of the pronotum projecting farther laterad than the shoulder.

Scutellum almost semicircular, grey. Elytra strongly punctate-striate, rather coarsely granulose, spotted with grey, brown, and blackish brown, almost chequered, the more conspicuous blackish brown spots are : a patch on subbasal callosity reaching base and enclosing a short grey basal dash in interspace III, a spot on shoulder angle, a larger rhombiform spot behind shoulder from margin to interspace VIII, an elongate-triangular sutural spot in middle, widest behind, and nearly the whole apical fourth except suture and two grey spots, in between these larger patches the grey pubescence broken up by spots and short lines. Pygidium with dispersed grey pubescence, as long as broad, strongly narrowed to apex, which is truncate-rotundate, the sides straight, but oblique.

Legs rufous, tarsi and apex of tibiae slightly darker than femora.

Length $2.7 \mathrm{~mm}$., width $1.35 \mathrm{~mm}$.

Malay Peninsula : Pahang, Frazer's Hill, 4,200 ft., July 1931 (H. M. Pendlebury), $1 \hat{\jmath}$.

\section{Nessiara gibba sp. nov.}

ô. Near N.tessellatus Eyd. \& Soul. 1839, but subbasal swelling of elytrum a high ridge.

Black, spotted with tawny-ochraceous; on pronotum an antemedian spot each side of middle; scutellum, a short line behind subbasal tubercle on each elytrum and a few small dots in median half of sutural and third interspaces white, vertical basal margin of elytrum whitish midway between scutellum and shoulder. 
Legs black, femora with some greyish ochraceous dots, middle of tibiae and the entire tarsi pale rufous, with grey pubescence.

Rostrum more coarsely punctate than in N. tessellatus; club of antenna broader, segment XI broader than long, slightly shorter than in N. tessellatus.

Length $11 \mathrm{~mm}$.

North Borneo : Bettotan, near Sandakan, 17.viii.1927 (C. B. Kloss \& H. M. Pendlebury), 1 ô.

22. Nessiara moluccarum sp. nov.

§. Close to $N$. optica Jord. 1894, described from Sumatra ; broader, black spots of pronotum larger; black-brown median sutural patch placed in front of the grey spot of each elytrum larger than the black-brown markings placed behind the grey spot, the two black lateral spots of elytrum between shoulder and middle larger than in $N$. optica, the grey spot in between them correspondingly smaller and rounded; pygidium broader than in $N$. optica, very slightly broader than long in $N$. moluccarum and a little longer than broad in $N$. optica ( $\hat{\sigma} \hat{\sigma})$.

Length of type $10 \mathrm{~mm}$., width $5 \mathrm{~mm}$.

Ceram : Piroe, ii.1900 (F. Muir), 1 ô, type ; Amboina (F. Muir), 1 ô.-

The Amboina specimen is much smaller (length $8.2 \mathrm{~mm}$., width $4.0 \mathrm{~mm}$.), the median carina of the underside of the rostrum is less elevate, and the pygidium broader than in type.

N. optica Jord. 1894 (Sumatra), N. robusta Jord. 1895 (Luzon), N. difficilis Jord. 1915 (Java), and N. moluccarum probably are geographical forms of one species. In all four segment XI of the antenna is short, being little longer than broad, the elytra are depressed at suture from before middle to apical declivity, interspace III not elevate.

\section{Oxyderes cyrtus modicus sp. nov.}

๙. Differs from O. c. cyrtus Jord. 1912, from Java (a single $q$ known to me), in the rostrum being a little shorter (ratio between length and width in $O$. $c$. cyrtus $1: 1 \cdot 58$, in $O$. c. modicus $1: 1 \cdot 34$ ), the lateral angle of the pronotal carina more acute, the black spots in the alternate interspaces of the elytra less elevate and less rounded, and many of them longer than broad, and in the grey rings of the femora and tibiae being narrower and less conspicuous.

Malay Peninsula: Selangor, Gomback valley, 16.x.1921 (H. M. Pendlebury), 1 ô.

\section{Oxyderes nasutus sp. nov.}

․ Like $O$. frenatus Jord. 1897, but the rostrum longer (ratio of length and width in $O$. nasutus $1: 1 \cdot 33$, in $O$. frenatus $1: 1 \cdot 70$ ) ; carina of rostrum prominent, continued farther back than in $O$. frenatus; club of antenna narrower ; eye shorter.

Malay Peninsula: Perak (W. Doherty), 1 q.-In Mus. Brit. a ô from Perak (Doherty) which shows the same differences.

\section{Oxyderes homalis sp. nov.}

․ Like O.f. frenatus Jord. 1897, differing only in the rostrum being shorter, twice as broad as long (ratio 14:7), and its median carina obsolescent, indicated at base as a thin longitudinal wrinkle and at apex as a slight swelling.

Sumatra (J. Gérard), 1 ㅇ. 
26. Apatenia viduata pulla subsp. nov.

o. Broader than A. v. viduata Pasc. 1859. Median carina of rostrum shorter, extending neither on to frons nor to the convex apical area. Frons strongly rugate-plicate longitudinally. Pronotum broader (length 10, width 12.3), somewhat more strongly punctate. Pygidium $(\hat{o})$ a little broader than long.

Length $5 \cdot 7$ to $8.5 \mathrm{~mm}$.; type, length $8 \cdot 5$, width $4 \cdot 0 \mathrm{~mm}$.

South Celebes: Tjamba, viii-ix.1891, and Macassar, vi.1896 (W. Doherty), 2 oิ $\hat{\sigma}^{2}, 2$ 우우.

\section{Apatenia viduata surda subsp. nov.}

§. Like the preceding subspecies, but carina of rostrum still shorter, terminating on a level with the thin transverse swelling which extends from the edge of the antennal groove mesad. Pronotum and elytra much shaded with claycolour. Pygidium $(\hat{\sigma})$ a little longer than broad.

Length $9 \mathrm{~mm}$., width $4 \cdot 3 \mathrm{~mm}$.

Batjan (W. Doherty), 1 ô.

\section{Apatenia madida sp. nov.}

o. Distinguished from A. viduata by the short rostrum, broad frons, and the absence of the black postmedian patch of the elytra.

Upperside clay-colour, dotted with brownish black. Rostrum more than one-half broader than long, a little more than the basal half depressed, apical area convex, middle carina confined to the depression, not ascending frons, which is anteriorly depressed and one-half as wide as the rostrum is long, proportions : width of frons $1 \cdot 0$, width of rostrum $2 \cdot 5$, length of rostrum $1.5 ;$ median apical lobe of rostrum prominent. Frons and occiput densely rugate-carinulate. Club of antenna distinctly decreasing in width from IX to XI.

Pronotum as in A. v. surda, basal median spot somewhat larger. Suture and alternate interspaces of elytra pustulated with black. Pygidium one-fourth broader than long, its basal transverse sulcus deep ; the two lobes of hypopygidium shorter and farther apart than in A. viduata.

Length $8.3 \mathrm{~mm}$., width $7 \cdot 0 \mathrm{~mm}$.

Batjan (W. Doherty), $1 \hat{\jmath}$.

\section{Apatenia grumosa sp. nov.}

․ Brownish black, pubescence drab. Rostrum coarsely punctate, twice as broad as long, basal half medianly depressed, in middle of rostrum the depression extended sidewards to margin of antennal groove, in the depression a longitudinal median swelling, subcariniform, not prolonged on to the frons. As on rostrum a few of the punctures on frons confluent; frons almost exactly as wide as the rostrum is long (q), anteriorly concave, with an indication of a median longitudinal swelling, which does not extend down to rostrum, and with a creamy median spot. On occiput a black patch with three projections, one median, the others directed towards eyes, which they nearly reach. Median groove on underside of rostrum shallow anteriorly, absent posteriorly. Segments I and II of antenna rufous.

Pronotum punctate, transversely depressed before middle, uneven, nearly one-fourth broader than long; a creamy median stripe from scutellum to trans- 
verse depression, pointed anteriorly and continued by a narrow subapical streak ; the portion behind carina longer than broad, seven longitudinal black markings at apex, the three dorsal ones subapically connected with each other; from transverse carina to depression five black markings, the median one bearing the creamy spot, the lateral ones including some drab pubescence, the intermediate ones narrow ; base behind carina black, with a buffish spot nearer to angle than to middle and continued across carina ; angle of carina a little larger than $90^{\circ}$, longitudinal carinula forming with dorsal carina an angle slightly smaller than $90^{\circ}$.

Scutellum creamy. Elytra one-third longer than broad, coarsely punctatestriate, pustulated with brown-black, at sides a large black patch from basal fourth of margin to behind middle, basal callosity high, rounded, another high rounded tubercle behind middle in interspace III, and before apical declivity a transverse oblique row of three tubercles, before apical margin of each elytrum a black transverse comma. Pygidium about one-tenth broader than long, convex subapically, elayish, with an abbreviated narrow brown median stripe and a short lateral one.

Prosternum pitted with large punctures, which are dispersed on basal lateral area; meso-metasternites likewise punctate, convex median area of metasternite almost impunctate. Abdomen punctate, more densely so on median area of segment I, sides almost impunctate apart from a basal row and a few additional punctures, at side a row of luteous spots set off by black. Legs rufescent-black, femora with a large blackish median patch or half-ring, a subbasal ring on tibiae and a narrow apical one, as well as the extreme bases of the tarsal segments and apex of I grey.

Length $6 \cdot 3 \mathrm{~mm}$., width $3 \cdot 1 \mathrm{~mm}$.

Boeroe: Ilat (W. Doherty), 1 ㅇ.

\section{Apatenia festiva sp. nov.}

‥ Nearest to A, sagax Jord. 1929, from Boeroe, but rostrum much longer, with the median carina strongly developed, and each elytrum with two high, pointed, subapical tubercles.

Rufescent-brown, pubescence pale chocolate variegated with lighter and darker shades. Rostrum a little more than one-half broader than long (ratio $1 \cdot 6: 1 \cdot 0)$, coarsely punctate, median carina high, reaching to apical margin and disappearing on anterior portion of frons, from eye an oblique cariniform swelling, distinct to middle, then gradually fading away, not reaching apical margin ; between the two carinae the rostrum deeply impressed; a small depression midway between eye and apical margin; from lateral dorsal apical angle of rostrum a carina runs basad to about one-half, parallel with margin of antennal groove; apical margin bisinuate, median lobe broad and projecting. Median channel on underside of rostrum distinct, extending to near transversely wrinkled neck. Frons half as wide as the rostrum, longitudinally rugate-plicate, crossed by a creamy anguliform line extending from eye to eye and projected a little forward on median carina. Occiput with large chocolate triangle of which the tip is rounded off, this patch narrowly bordered with creamy pubescence and divided by a creamy median line. Antenna brownish rufous, club less flattened than is usual in this genus (the nearest approach being found in A. sagax), IX and $\mathrm{X}$ almost alike, $\mathrm{X}$ being very slightly smaller, both rounded subapically and truncate, XI slightly smaller than $\mathrm{X}$, widest beyond middle, nearly as 
strongly narrowed basad as IX and X, apically gradually narrowed, almost elongate-lozenge-shaped.

Pronotum and elytra taken as a whole flattened, but very uneven ; pronotum almost exactly twice as broad as long $(2 \cdot 1: 1 \cdot 0)$, constricted before angle of carina ; lateral carina high, extending beyond middle, curved in dorsal aspect; pronotum about one-eighth narrower at end of lateral carina than at subbasal angle, dorsal surface depressed before middle, the depression deepest each side of median line and fading away in front of end of lateral carina ; median line raised in the depression; in area between dorsal and lateral carinae a large, shallow, rounded depression; a bell-shaped central patch reaches from near apical margin to base, occupying three-fourths of the base, narrowing frontad, consisting of various markings: a velvety black subapical arch divided by a creamy grey longitudinal line and thinly bordered with grey in front and behind, behind this arch a russet-chocolate arch, laterally expanding a little beyond the ends of the black arch and resting on a creamy grey transverse line situated at four-fifths from apex to carina, this line does not quite reach the sides of the patch; along posterior side of line a dark shade, which turns laterally at right angles towards carina; a large creamy grey patch before scutellum, rounded behind, expanding at carina and extending across it, forming a diffuse median stripe which joins the transverse line ; rest of the patch partly russet, particularly in the depressions; dorsal carina taken as a whole straight, but slightly wavy and medianly curved backwards, lateral angle $90^{\circ}$, with the tip rounded off, longitudinal carinula almost a straight continuation of the lateral carina, horizontal in lateral aspect.

Scutellum ereamy grey. Elytra one-half longer than broad, with lighter and darker shades, some of which have an oblique position, mainly backwardsdorsad; sides parallel from shoulder to three-fourths; between shoulder and middle a diffuse blackish brown limbal patch, dorsal surface except suture very uneven with numerous tubercles, three of which are particularly high, namely a subbasal one with two rounded tops (in interspaces III and IV), and two subapical ones, both the latter pointed and turned anad, one of them in interspace III, the other, somewhat higher, close to outer margin. Pygidium one-fifth broader than long, evenly rounded, clayish at base and apex.

Underside of thorax and middle of abdomen coarsely punctate, the sclerites more or less outlined with greyish clay-colour, a broad stripe, narrowest in front, from apical margin of prosternum to base of metepisternum cream-colour, thickly pubescent, limited above by the lateral carina of prothorax. Legs more or less pale rufous, middle of femora brown, base and apex pubescent whitish grey, tibiae whitish grey at base and extreme apex, otherwise brown, midtibia on outside blackish brown, hindtibia broadened, its apical two-thirds brownish black, as is the upperside of hindtarsal segment I except extreme tip, segments II to IV in all tarsi paler than I.

Length $6 \cdot 7 \mathrm{~mm}$., width $3 \cdot 0 \mathrm{~mm}$.

Mandated New Guinea: Bolan Mts., 1 \%

\section{Hypseus dilectus sp. nov.}

+. Similar to $H$. fascicularis Pasc. 1860 , but the club of the antenna and the colouring different, and the pygidium densely yellowish cream-colour.

Pale rufescent and blackish brown, variegated. Rostrum not quite twice 
as broad as long (ratio 1·8: 1·0), with short median eariniform swelling, proximally to which there is a depression that extends on to frons and is laterally bounded by a feeble swelling running from inner margin of eye obliquely forward ; apical margin of rostrum somewhat rounded, slightly bisinuate. Frons two-fifths the width of the rostrum, rugate-plicate, with pale median spot and narrow pale border to anterior margin of eyes, otherwise like occiput darker brown than rostrum. Segments I, II, VII, and VIII of antenna pale testaceous, the other segments of shaft rufescent-brown ; club flat, deeper brown, its segments decreasing in length and width, IX and $\mathrm{X}$ widest at apex, rounded-widened from close to base, apex truncate, XI ovate, with pale apex.

Pronotum punctate, transversely depressed before middle and before carina, with a transverse row of slight swellings in between ; apical dorsal median area ochreous, with an oblique, somewhat S-shaped, brown-black mark each side, from scutellum to median swelling a creamy white stripe, constricted before carina, rounded at both ends, at each side of this stripe a large square black-brown patch from which a short spur extends forward along white line into the ochreous patch; halfway between this patch and lateral carina a black-brown stripe stopping before middle at an ochreous dot surrounded with black-brown; dorsal carina feebly convex from side to side, medianly slightly incurved, lateral angle very little smaller than $90^{\circ}$, longitudinal carinula more strongly slanting than in $H$. fascicularis, forming equal angles with the dorsal and lateral carinae.

Scutellum ereamy white. Elytra blackish brown, an irregular stripe from shoulder to subapical tubercle ochreous, interrupted by the two posterior tubercles, subbasal swelling the same colour, which extends to base, interspaces V, VII, and IX with black pustules, in III behind middle and at beginning of apical declivity a rounded black tubercle, before apical margin a transverse tubercle or ridge, between the black pustules some grey dots. Pygidium entirely ochreous.

Abdominal segment I ochreous, II to $\mathrm{V}$ with brown lateral spot. Femora and tibiae dark brown, cn femora the base, a postmedian ring or spot and the apex pale testaceous, on tibiae an antemedian and a subapical ring and more or less also the base pale testaceous, as are the tarsi (of which segment I bears scattered dark hairs).

Length $4 \cdot 7 \mathrm{~mm}$., width $2 \cdot 0 \mathrm{~mm}$.

Ceylon: Bojuwantalura, 4,900-5,200 ft., 28.ii-12.iii.1882, type, and Dikoya, 3,800-4,200 ft., 6.xii.1881-16.ii.1882; 2 우우 in Mus. Brit. ex coll. G. Lewis.

\section{Phaulimia ofella sp. nov.}

§. Near Ph. priva Jord. 1895, but broader, blackish brown, the pronotum more coarsely granulate than in $P h$. priva and the frons a little wider. The luteous grey anguliform mark on occiput not quite $90^{\circ}$. On pronotum the grey markings more definite and more conspicuous on the dark ground, and those in anterior half larger, the lateral ones separate, not merged together as in $P h$. priva ; dorsal carina somewhat concave in middle, then convex and towards angle again slightly concave, lateral angle $90^{\circ}$, with the tip strongly rounded. Elytra with numerous very small grey dots in the rows of punctures, here and there a dot in the interspaces, an oblong postmedian spot in third interspace conspicuous, a smaller one at base of this interspace. 
Underside grey, abdomen medianly rufescent, tarsi paler rufous at apex.

Length $4 \mathrm{~mm}$., width $2 \mathrm{~mm}$.

North Borneo: Bettotan, near Sandakan, 19.vii.1927 (C. B. Kloss and H. M. Pendlebury), 1 ô.

Note.-In Nov. ZooL. xxxiv. p. 121 (1928) I gave a short definition of Ulorhinus Sharpe 1891 in which line 9 from above should read " Proboscis about twice as broad as long," instead of "twice as long as broad."

\section{Sintor peribalius sp. nov.}

․ Near S. philippinensis Jord. 1895, shorter, rostrum much shorter, with the carinae obsolete in basal half, club of antenna narrower and loose, segment $\mathrm{X}$ being triangular and longer than broad, and the lateral arm of the pronotal carina shorter.

Rufescent-brown or (immature) rufous, markings of upperside luteous or white, pubescence of underside silky grey. Rostrum one-tenth broader at apex than long $(\& ;$ in $\delta$ probably a little longer than in $q)$, almost cylindrical at base, median carina represented by a low swelling from near apical margin to middle, base slightly impressed, the impression continued on to frons; from margin of antennal groove to dorsal apical angle of rostrum a carina, but no carina from antennal groove to eye. On head a thin median stripe and a border to the eyes, uniting anteriorly, the upperside of the rostrum nearly entirely luteous. Segment II of antenna as long as III, IV like III, V to VIII decreasing in length, VIII being three-fourths III, segments of club longer than broad, IX one-tenth longer than III, X one-tenth shorter than III, both gradually widened from base, triangular, XI elongate-elliptical, one-tenth longer than IX.

Pronotum convex, depressed along carina, one-sixth broader than long, closely studded with shallow punctures (rings bearing each a hair), a thin median stripe, interrupted or anteriorly effaced, a sublateral stripe more or less interrupted before middle and behind the interruption somewhat curved sidewards (this lateral projection being a dot joined to the stripe), on each side of disc a median spot joined to the lateral stripe or isolated ; carina concave, very gradually flexed forward-laterad, with a very short horizontal portion, the side of the prosternite below the lateral carina more convex than in S. philippinensis.

Scutellum nearly white, conspicuous. Elytra convex, somewhat flattened along suture, more strongly punctate-striate than in $S$. philippinensis, alternate interspaces each with about seven dots and elongate spots, suture for the greater part luteous or white. Pygidium quite evenly rounded, one-half broader than long, medianly convex from base to near apex.

Tarsal segment I shorter than II to IV together.

Length 3.8 to $4.5 \mathrm{~mm}$.

Two subspecies :

(a) S. peribalius peribalius.

Markings of upperside luteous.

Pulo Tioman (east side of Malay Pen.) : B. Sedagong, 1,000 ft., v .1926; 3 우.

(b) S. peribalius leucas subsp. nov.

․ Markings of upperside white, lateral stripe of pronotum broken up into spots. Proboscis a little thicker, pronotum more coarsely granulose (without gloss), and elytra somewhat more convex. 
North Borneo: Bettotan, near Sandakan, 19.viii.1927 (C. B. Kloss and H. M. Pendlebury), 1 ㅇ.

\section{Morphocera gen. nov.}

§. Near Ancylotropis Motsch., eye less coarsely granulose, tooth of claw short, and tarsal segment III not enlarged.

Rostrum stout, long, cylindrical at bases, flattened and dilated at apex, without distinct earinae, apical margin truncate, with small median sinus, and the lateral angle projecting sideways on to the base of the mandible. Labium divided nearly down to the palpi ; labiophore glossy, truncate-emarginate, with the lateral angle acute. Antenna close to apex, segments III to $\mathrm{V}$ thicker than the others, strongly claviform, VI to VIII circular in transverse section, thin, widened at apex, but much less enlarged than the preceding ones, club flattened, wider than VIII, but narrower than V, IX conical, X shorter, XI elliptical; antennal groove rounded, slightly elliptical. Eye lateral a little longer than broad. Carina of pronotum distant from base, gradually flexed forward at side, not reaching middle; longitudinal and transverse carinulae vestigial, basal edge cariniform, a little projecting sidewards beyond the flank of the prosternite. Elytra with the subbasal swelling very faint, basal margin incurved from shoulder to shoulder. Pygidium semicircular. Mesosternal process gradually narrowing, very much narrower than coxa. Foretibia (ô) compressed, about as broad as forefemur, much broader than mid- and hindtibiae.-Genotype: $M$. pendleburyi sp. nov.

\section{Morphocera pendleburyi sp. nov.}

§. Brownish black, upperside densely irrorated with grey, the scale-hairs assuming a metallic green tint when looked at obliquely from their bases. Rostrum one-half longer than broad at its widest point, which is subapical, coarsely punctate-reticulate, with a vestige of a thin median carina, underside coarsely punctate, except labiophore, at each side about halfway between eye and buccal sinus a longitudinal groove. Head likewise coarsely reticulate, some of the meshes open, some of the ridges forming longitudinal carinulae; frons anteriorly one-tenth wider than the middle of the proboscis. Eye elliptical, one-third longer than broad. Antenna not quite reaching to apex of elytra, rufescent at base, segment $\mathrm{V}$ longest, widest behind middle, III and IV widest nearer apex, lengths of segments I 11, II 15, III 28, IV 27, V 34, VI 28, VII 22, VIII 19, IX 16, X 10, XI 15.

Prothorax one-tenth longer than broad, subconical, widest at basal third, evenly convex, highest in centre, slightly depressed along carina, coarsely punctate-reticulate, somewhat rugose and granulose, with numerous brownblack stiff hairs in between the speckles of grey pubescence; carina in middle just in front of basal seventh of pronotum, dorsally straight, laterally gradually flexed forward, the lateral arm oblique, not quite reaching to middle.

Scutellum small. Elytra cylindrical, not quite twice as long as broad (11:6), densely granulate, punctate-striate, the stripes rather shallow, but most of the punctures deep. Pygidium with narrow shallow longitudinal impression each side of middle line. 
Prosternum convex, densely and coarsely punctate ; rest of underside more granulate-coriaceous. Knees and tarsi rufescent, more densely pubescent-grey than middle of tibiae. Tarsi shorter than tibiae, segment I shorter than II to IV together.

Length $5 \mathrm{~mm}$.

Malay Pen. : Frazer's Hill, Pahang, 4,200 ft. (H. M. Pendlebury), 1 ô.

\section{Litotropis icon sp. nov.}

․ Blackish brown, elytra densely grey mixed with ochraceous, bearing a large lateral blackish brown patch. Rostrum sparsely irrorated with grey and ochraceous scale-hairs, one-half broader than long, with a shallow impression from middle to base, puncturation coarse and very dense, from inner margin of eye forward a cariniform wrinkle. Head with about a dozen longitudinal carinulae, variable, not quite regular. Antenna not quite reaching base of prothorax, rufescent, segment I shorter than II, II to VIII decreasing, club flattened, IX as long as III, triangular, a very little longer than broad, X broader than long, trapeziform, XI elliptical, but truncate at base, one-fourth longer than IX. Pronotum sparsely irrorated with grey, in middle of apical margin a small ochraceous cordiform patch bearing a white median line, before middle a transverse row of four small dots, the middle two or all four white, behind them indications of other dots ; one-fourth broader than long, widest at base, the side slightly incurved before angle and convex in middle, very densely punctatereticulate, the meshes larger in centre of disc than at sides, in posterior half some irregular transverse ridges variable in number and length; dise convex from side to side, without longitudinal depression.

Scutellum broader than long, white. Elytra three-fifths longer than broad, convex, not depressed along suture, subbasal swelling more or less distinct, lines of punctures feebly impressed, a spot on subbasal swelling and another on shoulder blackish brown like lateral area, this area extending from shoulder to apical third, reaching dorsal to fourth line of punctures. Pygidium semicircular.

Length : 6 to $7 \mathrm{~mm}$.

Borneo: Baram, x.1910, 1 ㅇ, type ; Kuching, v.1900, 1 \&; both received from the Sarawak Museum.

36. Caccorhinus castus sp. nov.

o. Black, above and below evenly pubescent grey-white; at each side of scutellum a spot, four-fifths $\mathrm{mm}$. long, longer than broad, posteriorly rounded and slightly dilated, in middle of elytrum a rounded dot (diameter about threefifths mm.), a smaller one laterally before middle and a still smaller one on shoulder, all black. Antenna pale rufous, club black, segment IX much longer than III, lengths of IX to XI 18, 14, 21, width of IX $8 \frac{1}{2}$, XI 9. Pygidium pale rufous, one-half broader than long, subtruncate, rather strongly convex each side at base, the basal transverse groove deep. Legs pale rufous, knees, tip of tibiae, and the entire tarsi black.

Length : $7 \cdot 3 \mathrm{~mm}$.

Malay Peninsula: Ketah, near Jitra, Catchment Area, 11th April 1928 (H. M. Pendlebury), 1 ô. 


\section{Caccorhinus modicus sp. nov.}

o. Narrower than $C$. castus sp. nov., pubescence of upperside less dense, luteous grey, the blackish derm shining through here and there. Club of antenna broader, length of IX 12, X 10, XI 18, width of IX 8, X 9, XI 9.5. Pronotum more flattened in middle, shorter (ratio of length and width $14: 17$ ), derm more coarsely sculptured. The two black basal spots on elytra confluent behind scutellum, a trilobate patch being formed, the median lobe on suture short and narrow ; a dorsal median spot and a lateral antemedian one. Luteous velvety median spot on metasternum quite small, elliptical. Legs darker brown than in C. castus. Knees and apices of tibiae more broadly black, segment I of tarsi grey except at extreme base and at apex.

Length: $7 \mathrm{~mm}$., width $2.7 \mathrm{~mm}$.

Tonkin: Hoa Bingh, 1 ô.

\section{Basitropis operta sp. nov.}

${ }^{1}$. . Nearest to B. tersa Jord. 1926 ; as in that species the rostrum with a median carina from apex on to frons, the club of the antenna constricted in the joints, and the legs unicolorous (apart from the slightly darkened knees). Distinguished by the antennal club being broader (but not as broad as in B. persimilis Jord. 1916), VI to VIII hardly at all increasing in width, in $\widehat{\sigma}$ VIII nearly twice as long as broad ( $8: 5$ ), half the width of IX, club three times as long as broad, IX $9, \mathrm{X} 8$, XI 13, width of X 10 ; in $q$ VIII as in $\hat{\jmath}$, club less than one-tenth shorter; in both sexes $\mathrm{X}$ one-ninth broader than IX and XI. Frons in $\hat{\sigma}$ half as broad as rostrum, in $q$ very little broader than in $\hat{\sigma}$.

Pronotum punctate, interspaces larger than the punctures and flat. Pronotum and elytra irregularly marmorated with buffish grey, this pubescence occupying about as much space as the brown ground-colour, a broadish submedian area from side to side almost entirely brown. Pygidium of os smooth, with dispersed punctures, convex, less than one-tenth broader than long, gradually narrowed, apex evenly rounded; in $q$ much broader than long (10:7), subtruncate, with the angles broadly rounded.

Java: G. Slamat, iv. 1917 (Drescher), 3 ô ô (type in Mus. Amsterdam) ; Malang, 1 ㅇ ; Tengger Mts., 4,000 ft. (Fruhstorfer), 1 ․

\section{Basitropis blanda sp. nov.}

․ Likewise near $B$. tersa, but the frons narrower, and the club of the antenna broader. Rostrum more coarsely rugate-punctate; antemedian knot of carina with the lateral extension directed obliquely backwards. Frons only twofifths the width of the rostrum. Occiput brown, border of eye luteous, as broad as segment IV of antenna is long. Antennal segments V to VIII very distinctly increasing in width, VIII one-ninth broader than long, club a little over twice as long as broad (25:11), more compact than in the previous species, IX and $\mathrm{X}$ much broader than long, $\mathrm{X}$ being nearly twice as broad as long, XI one-tenth longer than broad.

Pronotum punctate as in $B$. operta sp. nov., sides less rounded than in that species; with three somewhat irregular luteous stripes, above the lateral one a median spot attached to the stripe and farther back an isolated minute dot. 
Elytra nearly twice as long as broad (20:11), more extended brown than buff, the buff pubescence forming a large basal patch from lateral margin to near suture, leaving shoulder angle and basal margin brown, a postmedian band, oblique on each elytrum, more forward dorsally than laterally, interrupted at suture, a transverse subapical band leaving sutural angle brown; in between these luteous markings, which are somewhat irregular and probably variable, some small luteous spots. Pygidium semicircular, convex behind basal median groove. Legs and underside of body without spots, knees brownish.

Length : $5 \cdot 5 \mathrm{~mm}$., width $2 \cdot 2 \mathrm{~mm}$.

Philippines : Imugan, Luzon, 1 ㅇ.

\section{Anthribus vandykei sp. nov.}

§ิำ. Similar to A. fasciatus Forster 1773. Much larger, rostrum medianly impressed, this shallow impression continued across frons to occiput. Pronotum likewise with a median depression from near apex to near base, side of pronotum more strongly dilated in middle than in A. fasciatus, straight from this widened portion to base, angle a little larger than $90^{\circ}$, much more strongly rounded than in A. fasciatus, dorsal carina medianly less concave. Scutellum much larger. Alternate interspaces of elytra more strongly elevate, on the whole more conspicuously brick-red than the flat interspaces, dorsal black spots from basal fifth backward all short. Pygidium as in A. fasciatus coarsely punctate-reticulate, brick-red like underside of abdomen. Legs as in A. fasciatus, tibiae somewhat wider.

Length : 5 to $6 \mathrm{~mm}$.

China: Nanking, 3.v.1923 (E. C. Van Dyke), several specimens bred from a large Kermes found on Oak ; type in coll. Van Dyke, paratype at Tring. 


\section{$2 \mathrm{BHL}$ Biodiversity Heritage Library}

1933. "New oriental Anthribidae (Coleoptera)." Novitates zoologicae : a journal of zoology in connection with the Tring Museum 38, 362-383.

https://doi.org/10.5962/bhl.part.14756.

View This Item Online: https://www.biodiversitylibrary.org/item/22934

DOI: https://doi.org/10.5962/bhl.part.14756

Permalink: https://www.biodiversitylibrary.org/partpdf/14756

\section{Holding Institution}

Natural History Museum Library, London

\section{Sponsored by}

Natural History Museum Library, London

\section{Copyright \& Reuse}

Copyright Status: In copyright. Digitized with the permission of the rights holder.

Rights Holder: The Trustees of the Natural History Museum, London

License: http://creativecommons.org/licenses/by-nc-sa/4.0/

Rights: http://biodiversitylibrary.org/permissions

This document was created from content at the Biodiversity Heritage Library, the world's largest open access digital library for biodiversity literature and archives. Visit BHL at https://www.biodiversitylibrary.org. 